\author{
Review Article \\ www.ijrap.net (ISSN:2229-3566)
}

\title{
FUNCTIONAL AND PHARMACOLOGICAL PROPERTIES OF BHRINGARAJA: A REVIEW
}

Sneha S Air ${ }^{1 *}$, Pravin M Bhat ${ }^{2}$

${ }^{1}$ M.S. Scholar, Department of Shalakya Tantra, Sumatibhai Shah Ayurved Mahavidyalaya, Hadapsar, Pune, Maharashtra, India

${ }^{2}$ Associate Professor, Department of Shalakya Tantra, Sumatibhai Shah Ayurved Mahavidyalaya, Hadapsar, Pune, Maharashtra, India

Received on: 10/07/21 Accepted on: 01/09/21

\author{
*Corresponding author \\ E-mail: snehaair2912@gmail.com
}

DOI: $10.7897 / 2277-4343.1205146$

\begin{abstract}
Bhringaraja (Eclipta alba) of the Asteraceae family is used in various Kalpa to treat eye disease because of its Chakshushya properties. It is also used in naktyandhtva and widely used in liver disease, anemia, eye disease, problem-related to hairs. It is having antibacterial, analgesic, antifungal, antiviral, antihepatotoxic, immunomodulatory, neuroprotective properties. It contains chemical compounds including coumarins, alkaloids, flavonoids etc. Because of these properties, it is used in various eye diseases. The eye is also made from the Panchamahabhutas like other body parts. Every part of the body is developed from a neural tube i.e., ectoderm and mesoderm like this every part or layer of the eyeball develop from the optic vesicle, the ectoderm and mesoderm, as the origin is the same. Also, many eye-related symptoms are seen in various systemic diseases. Eclipta alba can be used in various diseases which has ocular manifestation with different concentrations and in various formulation with appropriate concentration along with other herbs. So, we need to develop appropriate formulation for evidence-based medicine.
\end{abstract}

Keywords: Eclipta alba, Bhringaraja, Eye disease, Ayurveda

\section{INTRODUCTION}

Ayurveda is our traditional science with a holistic approach to health and personalised medicine. It is a complete medical system; it comprises physical, psychological, philosophical, ethical, and spiritual health. It helps in preventing diseases and treating them the same. The disease is developed if there is no equilibrium between Tridosha, Sapta dhatu and Tri malas. Treatment is done by using herb i.e., properties of herb viz (rasa, veerya, vipaka guna) which are opposite to the properties of dosha, dhatu, malas which are vitiated.

Bhringaraja (Eclipta alba) is one of the dravya brought from nature which is known for its medicinal and therapeutic properties. It is an annual herbaceous plant commonly known as a false daisy. It has been used in various parts of South America, Asia, and Africa. It is growing throughout India by marshes, rivers, and lakes in the rainy season. It is erect or prostrate, these are of the 3 types: Shweta, Pita, Krishna. The genus name come from the Greek word "Deficient" meaning absence of bristles and awns on the fruits.

It is used as a liver tonic, immune-modulatory, antihemorrhagic, analgesic, antimitotic, anti-hyperglycaemic, antibacterial, antiinflammatory properties, and a good rejuvenator. The main active principles of coumarins are wedelolactone, demethylwedelolactone. $^{1} \quad$ Furanocoumarin oleanane and taraxastane glycosides. ${ }^{2}$

In Ayurveda classic, the properties of Bhringaraja are tikta, ushna, deepana, pachana, vatanulomana, rasayana, kaphavatahara, Chakshushya, twagdoshahara, keshya, varnya, Krimighna, balya.
The eyes are a very valuable organ in our body. It is like the sun in the sky nothing can be compared with vision. Doshas in the eye which are responsible for normal functioning when get vitiated leads to diseases. It is considered that Alochaka pitta in the eye is responsible for visual perception ${ }^{3}$ also it is having teja dominant mahabhuta. ${ }^{4}$ Due to drastic changes in lifestyle along with climatic change and pollution, these are affecting human beings and developing various diseases.

\section{MORPHOLOGY}

\section{Botanical Description}

Bhringaraja is herbaceous annual, $30-50 \mathrm{~cm}$ high, erect, or prostrate plant. It is much-branched, strigose hirsute, often rooting at the node. A common weed of moist places found throughout India ascending to $1700 \mathrm{~m}$. Well-developed roots have several secondary branches arising from the main root they are cylindrical, greyish.

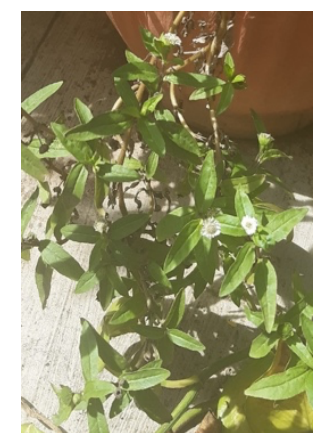

Figure 1: Bhringaraja 
The stem is herbaceous, branched, occasionally rooting at nodes, cylindrical or flat, rough due to oppressed white hairs, node distinct, greenish, and occasionally brownish.

Leaves are opposite, sessile to subsessile, 2.2 - $8.5 \mathrm{~cm}$ long, 1.2 $2.3 \mathrm{~cm}$ wide, usually oblong, lanceolate, sub-entire, sub-acute or acute with oppressed hairs on both surfaces.

Flowers are solitary or two, together on unequal axillary peduncles; involucre bracts about eight ovate, obtuse or acute, herbaceous, strigose with oppressed hairs, ray flowers ligulate, ligule small, spreading, scarcely as long as bracts, not toothed, white, disc flowers tubular, corolla often four toothed; pappus absent, except occasionally very minute teeth on the top of achene; stamen five, filaments epipetalous, free, anthers united into a tube with base obtuse; pistil bicarpellary; ovary inferior, unilocular with one basal ovule. ${ }^{5}$

\section{Taxonomic hierarchy of Eclipta alba}

Kingdom - Plantae

Subkingdom - Viridaeplantae

Infrakingdom - Streptophyta

Division - Tracheophyta

Subdivision - Spermatophytina

Infra division - Angiospermae

Class - Magnoliopsida

Superorder - Asteranae

Order - Asterales

Family - Asteraceae

Genus - Eclipta L.

Species - Eclipta alba (L.) Hassk

Table 1: Phytoconstituents of Eclipta alba ${ }^{6-9}$

\begin{tabular}{|c|c|}
\hline Nature of phytoconstituents & Phytoconstituents \\
\hline Coumestan & $\begin{array}{l}\text { Wedelolactone, demethylwedelolactone, } \\
\text { demethylwedelolactone-7-glucoside }\end{array}$ \\
\hline $\begin{array}{l}\text { Terpenoids and their } \\
\text { glycosides }\end{array}$ & $\begin{array}{c}\text { Eclalbasaponins VII-X (taraxastane triterpene glycosides), eclalbasaponins I-VI (oleanane triterpene } \\
\text { glycosides), eclalbosaponins I-VI (triterpene glycosides), ecliptasaponins C and D (triterpenoid glucosides), } \alpha \text { - } \\
\text { amyrin, oleanolic acid, ursolic acid (triterpenoids) }\end{array}$ \\
\hline Sterol & Stigmasterol, daucosterol, stigmasterol-3-O-glucoside \\
\hline Alkaloids & 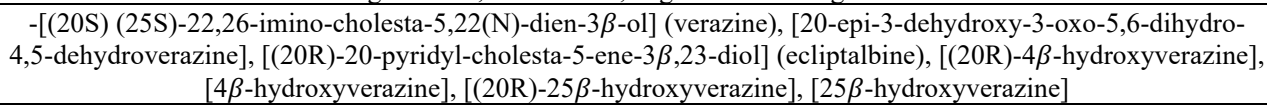 \\
\hline Flavonoids & - Luteolin-7-glucoside, luteolin, apigenin, orobol (isoluteolin) \\
\hline Sesquiterpene lactones & $\begin{array}{c}\left.\text { 5-hydroxymethyl-(2,2'.5', } 2^{\prime \prime}\right) \text {-terthienyl tiglate, 5-hydroxymethyl-(2,2':5', ,'”)-terthienyl agelate, 5- } \\
\text { hydroxymethyl-(2,2':5',2”)-terthienyl acetate }\end{array}$ \\
\hline Terthienyl aldehyde & Ecliptal \\
\hline Fatty alcohols & Hentriacontanol, heptacosanol \\
\hline Volatile oils & $\begin{array}{l}\text { - Heptadecane, 6,10,14-trimethyl-2-pentadecanone, n- 10. hexadecanoic acid, pentadecane, eudesma-4(14),11- } \\
\text { diene, phytol, octadec-9-enoic acid, 1,2-benzenediacarboxylic acid diisooctyl ester, }(Z, Z)-9,12 \text {-octadecadienoic } \\
\text { acid, (Z)-7,11-dimethyl-3-methylene-1,6,10-dodecatriene, }(Z, Z, Z)-1,5,9,9 \text {-tetramethyl-1,4,7-cycloundecatriene }\end{array}$ \\
\hline Saponins & Eclalbatin (triterpene saponin), dasyscyphin C \\
\hline Polyacetylinic compounds & $\alpha$-Terthienylmethanol, polyacetylenes, polyacetylene substituted thiophenes \\
\hline Phenolic acids & Protocatechuic acid, 4-hydroxy benzoic acid \\
\hline
\end{tabular}

Table 2: Properties of Bhringaraja (Eclipta alba)

\begin{tabular}{|c|c|c|}
\hline Keshya (promotes hair growth) & Varnya (improves skin complexion) & Chakshushya (increase eyesight) \\
\hline Hepatic stimulant & Digestive stimulant & Appetizer \\
\hline Cholagogue (promotes the discharge of bile) & Detoxifying & Anroprotective \\
\hline Analgesic & Antihypertensive & Antihelminthic \\
\hline Hematogenic & Carminative & \\
\hline
\end{tabular}

Table 3: Pharmacological activities of chemical constituents ${ }^{10}$

\begin{tabular}{|c|c|c|}
\hline Chemical constituents & Pharmacological activities & Plant part \\
\hline Wedelolactone & Antihepatotoxic, Trypsin inhibitor Antibacterial, Antivenom. & Leaves. \\
\hline Eclalbosaponine & Hair revitalizing, Antigiardial, Antiproliferative & Whole plant \\
\hline Demethylwedelolactone & Antihepatotoxic, Dye, Antihaemorrhage, Antivenom, & Leaves \\
\hline Dasyscyphin C & Antiviral, Anticancer & Stem \\
\hline Eclalbatin & Antioxidant & Root plant \\
\hline Ecliptalbine, Verazine & Lipid-lowering & Stem \\
\hline
\end{tabular}

\section{Vernacular Names}

- Botanical name - Eclipta alba

- Common name - False Daisy

- Hindi - Bhringaraja, Bhangra, Mochkand, Babri

- Bengali-Kesuriya

- Gujarati - Bhangaro

- Kannada - Garagadasoppu, Garugalu, Kadiggagaraga

- Malayalam - Kannunni, Kaikeshi

- Marathi - Bhringuraja, Maka

- Sanskrit - Kehraj, Bhringaraja, Bhangra
- Tamil - Karisalaankanni, Garuga, Kayanthakara

- Telugu-Galagara

- Urdu - Babri, Bhangr

\section{Antibacterial Activity}

The chemical wedelolactone which is present in Bhringaraja is having antibacterial properties and has proven effective. $S$. epidermidis, S. typhimurium, Staphylococcus aureus, $P$. aeruginosa, S. fslexneri, E. coli. ${ }^{11}$ Infection of these microbes develop diseases in the coat of eyeball viz conjunctiva, cornea, uveal tract, sclera, dacryocystitis, blepharitis. 


\section{Antiviral Activity}

Eclipta alba extract having strong antiviral activity. ${ }^{12}$ So, it can be used in viral eye disease. Like viral keratitis or other viral diseases.

\section{Antifungal activity}

Crude saponins extract of Eclipta alba has good antifungal properties and is effective against $F$. solani, A. flavus, A. niger. Also, Alkaloids crude extracts having antifungal, effective against $F$. solani, $A$. flavus. Flavonoids crude extract from alba effective against $F$. solani, A. flavus. ${ }^{13}$

\section{In aspergillums fumigates keratitis}

Wedelolactone reduces host immune responses. It is attenuating neutrophil recruitment and IC - IB maturation as aspergillus fumigates keratitis and decreases MPO level (Myeloper oxidase). Pre-treatment with wedelolactone inhibits caspase -1 activity so it decreases pro-inflammation cytokine interleukin 1beta (IL-1B) Maturation. Wedelolactone combined with an antifungal medicine could be a potential therapy for reducing lesion severity in fungal keratitis. ${ }^{14}$

\section{Effect of Eclipta alba on memory and learning}

Cholinergic dysfunction and suppression of the immune system have been implicated in inducing cognitive deficits in the neuronal memory circuits. Eclipta alba produces a significant reduction in the transfer latency. When tested after an interval of 24 hours in the EPM.

It indicates that it improves the ability to retrieve information and therefore it strengthens explicit memory. In special habitual learning, the exploratory rearing is significantly reduced with time indicating improved memory. Luteolins possessing credible enhancement of the central cholinergic receptors.

Luteolins being an active constituent in the extract of Eclipta alba. It may be responsible for minimizing cognitive deficits due to cholinergic dysfunction. Their profound free radical scavenging action could insulate neuronal tissues from degeneration. Due to the immune-modulatory action of Eclipta $a l b a$, it preserves these areas from stress perturbation. Therefore, Eclipta alba can serve as a potential memory modulatory. ${ }^{15}$

Alochaka Pitta, which is one of the types of Pittas, situated in Chakshu, has 2 types Chakshuvaisheshik and Buddhivaisheshik. ${ }^{16}$ They work for the formation and storage of the image. Chakshuvaisheshik means through coats of eyeball the ray from any object falls on the retina which is visualised and Buddhivaisheshik is the formation of an image of an object through the nervous route. Any deformity in these routes can cause diseases. So, the Chakshushya karma of Bhringaraja may work in this way by keeping the Alochaka pitta and its type in the equilibrium state.

\section{Antihepatotoxic properties}

Eclipta alba root extract is a powerful liver tonic. It possesses a wide range of biological activities and is used for the treatment of hepatitis and cirrhosis. ${ }^{17}$ The plant contains an alkaloid, ecliptine. It has choleretic action and lipid peroxidation the extract augmented bile flow in rats. It suggests stimulation of liver secretory capacity. ${ }^{18}$

Eclipta alba has a protective role against liver diseases such as liver cirrhosis and infective hepatitis. The components of Eclipta alba extract wedelolactone demethylwedelolactone, mononuclear infiltration necrotic foci stimulate the regeneration of hepatocytes in the liver. ${ }^{19}$
Liver disorder in which symptoms related to eyes are seen are as follows ${ }^{20}$

\section{- Xanthelasma}

They are associated with hyperproteinaemia's cholestasis and primary biliary cholangitis.

\section{- Conjunctival icterus}

Seen when plasma bilirubin levels rise above the normal level.

\section{- Keratoconjunctivitis sicca / Dry eye}

It can be caused by primary biliary cholangitis and chronic hepatitis $\mathrm{C}$ virus infection. Prolonged dry eye can result in a multitude of symptoms including grittiness or foreign body sensation, blurred vision, redness epithelial erosion and infection.

\section{- Kayser - Fleischer Rings}

They are thought to be pathognomonic for Wilson's disease and should be considered secondary to Wilson's disease. This ring rarely can be seen also in primary biliary cirrhosis and primary sclerosing cholangitis. Kayser - Fleischer rings are due to copper deposition in the Descemet membrane. They are seen in the peripheral cornea. It first occurs superiorly and gradually spread circumferentially and inferiorly.

\section{- Sunflower cataract}

It is secondary to copper deposition in the eye. It is an ocular manifestation of Wilson's disease. Copper deposits on the anterior and posterior lens capsule. Also, other several liver diseases can cause lens opacities - includes galactosemia, Zellweger hepatoCerebro-renal syndrome, adrenoleukodystrophy, neonatal haemolytic jaundice syndrome.

\section{- Post. Embryotoxon}

Alagille syndrome is an autosomal dominant cholestatic liver disease associated with multiple ocular abnormalities including keratoconus, refractive error, band keratopathy, chorioretinal changes and anomalous optic disc. Post embryotoxic is a corneal finding and represents a thickened and anterior displaced termination of the Descemet membrane.

\section{- Cranial nerve Abnormalities}

Liver disease can cause cranial nerve abnormalities that present as gaze palsy or nystagmus. These are various signs seen in the eye due to the pathology which occurs in the liver. To reduce these signs, we must break the pathology occurring in the liver. Because of good liver tonic action, Bhringaraja can be used.

\section{- Analgesic}

Eclipta alba has antinociceptive activity, which is used in painrelieving treatment ${ }^{21}$. As Bhringaraja has Roojahara properties.

\section{- Antioxidant}

Eclipta alba contains alkaloids, phenolic, Compounds, flavonoids, tannins, ascorbic acid content i.e., their constituent having antioxidant activities. ${ }^{22-25}$

\section{- Neuroprotective function}

Curcumin, luteolin and DHA have beneficial effects on supplemented mouse retina and brain. The mixed populations of microglia seen in the retina suggest that these supplements can to some extent attenuate microglia activation coinciding with a more functional retina. Furthermore, these anti-inflammatory substances could have further beneficial effects when paired with different therapies. So, it can be used in optic neuropathies as it works as nerve protection on the retina. ${ }^{26}$ 


\section{- Hair growth activity}

Eclipta alba is a well-known Ayurvedic herb for hair growth. Bhringaraja in hair oil preparation promotes hair growth and maintains hair black. ${ }^{12}$

\section{Formulations}

Bhringaraja taila, Haridradyavarti, Netrashanirasa, Bhrigarajadi churna, Krumikuthar rasa, Bhringaraja churna, Bhringaraja ghrita, Bhringarajasav, Mahabhringaraja taila, Narsingha rasayana, Neelibhringyadi taila, Shadbindu taila, Sutshekhar rasa.

\section{CONCLUSION}

Eclipta alba is a medicinal plant having significant properties for the treatment of various diseases. It has various chemical constituents which are useful in treating diseases. It inhibits the growth of bacteria, fungus, viruses also inhibit the growth of cancerous cells. It is used in memory enhancing. It is used as an antioxidant and having antihepatotoxic activities. By using these properties of Bhringaraja, we can treat the disease of the eyes. Also using these principles, we must do further studies on various eye diseases. It is a need to find out various and proper drug of choice to treat eye disease with appropriate concentration.

\section{REFERENCES}

1. Wagner H. et al. Coumestans as the main active principles of the liver drugs Eclipta alba and Wedelia Calendulaceae Planta Med 1986; 5: 370-74.

2. Amritpal Singh, Sanjiv Duggal, Asish Suttee, Jaswinder Singh, Shankar Katekhaye. Eclipta alba Linn. - Ancient remedy with therapeutic potential. IJP 2010; 1(2): 57-63.

3. Shastri A, editor. Sushruta Samhita Sutra Sthana vranprashnya adhyaya $4^{\text {th }}$ ed. Varanasi: Chaukhambha Prakashan, vol. 2. p. 115.

4. Borkar D, Sushrut Samhita Sharir Sthana sarvabhootchinta sharira adhya, Rajesh Prakashan, vol. 1. p. 318.

5. Yadav P, Harisha C, Prajapati P. Validation of pharmacopoeial character of Bhringaraja Journal of Current Pharmaceutical Research 2011; 8(1): 17-24.

6. N. M. Mithun, S. Shashidhara, and R. Vivek Kumar. Eclipta alba (L.) A review on its phytochemical and pharmacological profile, Pharmacology online 2011; 1: 345-357.

7. R. K. Upadhyay, M. B. Pandey, R. N. Jha, and V. B. Pandey. Eclalbatin, a triterpene saponin from Eclipta alba, Journal of Asian Natural Products Research 2001; 3(3): 213-217.

8. M. Zhang, Y. Y. Chen, X. H. Di, and M. Liu. Isolation and identification of ecliptasaponin D from Eclipta alba (L.) hassk, Yao Xue Xue Bao 1997; 32(8): 633-634.

9. M. Zhang and Y. Chen. Chemical constituents of Eclipta alba (L.) Hassk, Zhongguo Zhong Yao Za Zhi 1996; 21(8): 48: 510 .

10. Neeraja P.V. Elizabeth Margaret, Eclipta alba (L) Hassk: A valuable medicinal herb. ICCPR 2011; 2(4): 188-197.

11. Dalal, Sunita; Kataria, Sudhir K.; Sastry, K. V. and Rana, SVS. Phytochemical Screening of Methanolic Extract and Antibacterial Activity of Active Principles of Hepatoprotective Herb, Eclipta alba, Ethnobotanical Leaflets 2010; 3(3): 248-258.

12. Ganesh Kumar Anbazhagan, Sankarganesh Palaniyandi and Baby Joseph. Antiviral Plant Extracts, Plant Extracts, Aman Dekebo, Intech Open, DOI: 10.5772/intechopen.85126.
Available from: https://www.intechopen.com/chapters/ 67686

13. Iqbal Hussain, Naeem Khan, Riaz Ullah, Shanzeb, Shabir Ahmed, Farhat Ali Khan and Sultan Yaz. Phytochemical, the physiochemical and anti-fungal activity of Eclipta alba, African Journal of Pharmacy and Pharmacology 2011; vol.5 (19): 2150 - 2155. Article Number - E7CF65031058.

14. Cheng M, Lin J, Li C, Zhao W, Yang H, Lv L, Che C. Wedelolactone suppresses IL-1 $\beta$ maturation and neutrophil infiltration in Aspergillus fumigatus keratitis. Int Immunopharmacol 2019 Aug; 73: 17-22.

15. Otilia Banji, David Banji, Annamalai A.R, Manavalan R. Investigation on the effect of Eclipta alba on animal models of learning and memory, Indian J Physiol Pharmacol 2007; 51(3): 274-278.

16. Shastri, V. and Sarma, C, editors, Bhela Samhita, Sharir Sthana, purushnichaya sharira adhyaya New Delhi: Literary Research Unit, T.M.S.S.M. Library Thanjavur; 1977. p. 178.

17. Wagner H. Coumestans as the main active principles of the liver drugs Eclipta alba and Wedelia calendulacea. Planta Med 1986; 5: 370-374.

18. Murugaian P, Ramamurthy V, Karmegam N. Hepatoprotective Activity of Eclipta alba L. Against Acute Hepatotoxicity in Rats. Res J Agri Bio Sci 2008; 6: 685-687.

19. Satheesh Naik K, Gurushanthaiah M, Kavimani M, Prabhu K, Lokanadham S. Hepatoprotective Role of Eclipta alba against High Fatty Diet Treated Experimental Models - A Histopathological Study. Maedica (Bucur) 2018 Sep; 13(3): 217-222.

20. Tooley AA, Sweetser S. Clinical examination: Eyes. Clin Liver Dis (Hoboken) 2016; 7(6): 154-157. Published 2016 Jun 28. DOI: 10.1002/cld.561

21. Pandey PS, Upadhyay KK, Pandey DN. Experimental evaluation of the analgesic property of Eclipta alba (L) hassk. Anc Sci Life 1997 Jul; 17(1): 36-40.

22. Molina L, Constantinescu F, Michel L, Reimmann C, Duffy B, Defago G. Degradation of pathogen quorum sensing molecules by soil bacteria: a preventive and curative biological control mechanism. FEMS Microbiology Ecology 2003; 45: 71-81.

23. Gholivand K, Mahzouni HR, Pourayoubi M, Amiri S. Inorganic Chemistry 2010; 363: 2318-2324.

24. Rice-Evans CA, Miller NJ, Bolwell PG, Bramley PM, Pridham JB. The relative antioxidant activities of plantderived polyphenolic flavonoids. Free Radical Research 1995; 23: 375-383.

25. Arlorio M, Coisson JD, Travaglia F, Varsaldi F, Miglio G, Lombardi G. Antioxidant, and biological activity of phenolic pigments from Theobroma cacao hulls extracted with supercritical $\mathrm{CO}_{2}$. Food Research International 2005; 38: 1009-1014.

26. Myriam Mirza, Cornelia Volz, Herbert Jägle, Thomas Langmann, Effects of food supplementation on CLN6nclf mice.; Curcumin, Luteolin and DHA Supplementation Abates Microglia Activation and Retinal Degeneration in the CLN6nclf Neuronal Ceroid Lipofuscinosis Mouse Model. Invest. Ophthalmol. Vis. Sci 2013; 54(15): 159.

\section{Cite this article as:}

Sneha S Air and Pravin M Bhat. Functional and Pharmacological properties of Bhringaraja: A Review. Int. J. Res. Ayurveda Pharm. 2021;12(5):63-66 http://dx.doi.org/10.7897/2277$\underline{4343.1205146}$

Source of support: Nil, Conflict of interest: None Declared

Disclaimer: IJRAP is solely owned by Moksha Publishing House - A non-profit publishing house, dedicated to publishing quality research, while every effort has been taken to verify the accuracy of the content published in our Journal. IJRAP cannot accept any responsibility or liability for the site content and articles published. The views expressed in articles by our contributing authors are not necessarily those of IJRAP editor or editorial board members. 